\title{
ERrata $^{1}$
}

Errata referente ao artigo do v. 26, n. 4, 2020

Título: Uma versão em português da Medida de Processamento Sensorial para Pré-escola: Análise da Consistência Interna e Homogeneidade dos Itens da Forma Escolar

Autoras:

Helena Isabel Silva REIS

http://orcid.org/0000-0002-3589-8354

Onde se lê: Maria Dulce NEVES

Leia-se: Maria Dulce GOMES

http://orcid.org/0000-0003-4526-3990

Maria dos Anjos DIXE

http://orcid.org/0000-0001-9035-8548

${ }^{1}$ DOI: https://doi.org/10.1590/1980-54702020v27e0165 
